\title{
Determination of the Paracoccus denitrificans SOS box
}

\author{
Alfonso del Rey, Julio Diestra, Antonio R. Fernández de Henestrosa and \\ Jordi Barbé
}

\author{
Author for correspondence: Jordi Barbé. Tel: +34 93 5811837. Fax: +34935812387. \\ e-mail: jbarbe@cc.uab.es
}

Molecular Microbiology and Bacterial Genetics Group, Department of Genetics and Microbiology, Autonomous University of Barcelona, Bellaterra, 08193 - Barcelona, Spain

\begin{abstract}
By gel retardation experiments with crude cell extracts of Paracoccus denitrificans it was demonstrated that a protein specifically binds to the promoter of the $P$. denitrificans recA gene. PCR mutagenesis of the recA promoter showed that the GAACN,GAAC motif is required for the formation of the DNA-protein complex. This protein also binds to the $\mathrm{GTTCN}_{7} \mathrm{GTTC}$ motif, which is present in the promoter of the $P$. denitrificans uvrA gene. Mutational analysis of the promoter regions of both $P$. denitrificans recA and uvrA genes indicated that the GAACN, GAAC and $G T T C N_{7} G T T C$ sequences are required for DNA-damage-mediated induction of these two genes in vivo. Furthermore, the $P$. denitrificans recA gene was DNA-damage-inducible when introduced into cells of the phylogenetically related phototrophic bacterium Rhodobacter sphaeroides, although this inducibility was lost in mutants in the GAACN, GAAC motif. These results indicate that $P$. denitrificans possesses the same SOS box as $R$. sphaeroides, which, in agreement with previous work, is proposed as being the $\mathrm{GTTCN}_{7} \mathrm{GTTC}$ motif.
\end{abstract}

Keywords: recA gene, uvrA gene, SOS box, Paracoccus denitrificans, DNA damage

\section{INTRODUCTION}

DNA damage induces in Escherichia coli cells the expression of a set of genes whose encoded proteins are directly involved in DNA repair or in enabling the cell to tolerate the lesion until repair occurs (Little \& Mount, 1982; Walker, 1984). This set of genes, which constitutes the SOS system, is under the control of both RecA and LexA proteins. The LexA protein is the common repressor of the SOS network, which also includes both recA and lexA genes. RecA promotes proteolytic inactivation of LexA in DNA-damaged cells (Little, 1991). Several studies indicate that the RecA protein binds to single-stranded DNA regions, originated by DNAdamage-mediated replication inhibition or enzymic processing of broken DNA ends, and is converted into an active conformation (Sassanfar \& Roberts, 1990). Once activated, RecA facilitates autocatalytic cleavage of LexA, giving rise to the expression of the SOS genes. When DNA has been repaired, the RecA protein is no longer activated and the level of the LexA repressor increases, again blocking expression of the SOS genes.

Similar DNA repair systems have been reported in other

The GenBank/EMBL/DDBJ accession number for the sequence determined in this work is AJ007707. bacteria (Miller \& Kokjohn, 1990). In this way, the regulatory genes of the SOS system, $\operatorname{lex} A$ and $\operatorname{rec} A$, of different Gram-positive and Gram-negative bacteria have been characterized (Raymond-Denise \& Guillen, 1991; Garriga et al., 1992; Roca \& Cox, 1997). E. coli and Bacillus subtilis LexA proteins bind to a specific site located at the $5^{\prime}$ end of their respective SOS genes which is known as the SOS box. So far, three different SOS boxes have been identified. The first one, which was initially described in E. coli, displays the dyad sym-

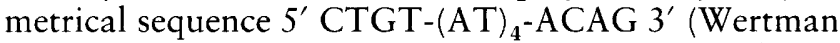
\& Mount, 1985; Lewis et al., 1994). This E. coli-like SOS box is present in a great number of Gram-negative bacterial species belonging to several taxonomic families (Enterobacteriaceae, Pseudomonadaceae and Pasteurellaceae, among others). The second SOS box known, whose consensus sequence is $5^{\prime}$ CGAACRNRYGTTYC 3' (Winterling et al., 1998), was first reported in B. subtilis (Cheo et al., 1991), although it is also present in many other Gram-positive bacteria (Movahedzadeh et al., 1997; Durbach et al., 1997; Johnston et al., 1997). Finally, a third SOS box belonging to the phototrophic bacterium Rhodobacter sphaeroides has recently been identified (Fernández de Henestrosa $e t$ al., 1998). This displays the GTTCN ${ }_{7}$ GTTC motif, and is the first SOS box known whose sequence is a direct repeat. 
Paracoccus denitrificans is an aerobic soil bacterium which, taxonomically, has been grouped in the $\alpha$ subclass of the Proteobacteria together with $R$. sphaeroides (Woese et al., 1984). The recA gene of $P$. denitrificans has been isolated and sequenced, and it has been shown to be DNA damage-inducible despite its promoter lacking an E. coli-like SOS box (Fernández de Henestrosa et al., 1997). In this work, to determine whether the R. sphaeroides SOS box is uniquely present in this organism or is also found in other members of the Proteobacteria, the promoters of the $P$. denitrificans recA and uvrA genes were mutagenized and their behaviour in vitro and in vivo was analysed.

\section{METHODS}

Bacterial strains, plasmids and growth conditions. The bacterial strains and plasmids used in this work are listed in Table 1. E. coli was grown at $37^{\circ} \mathrm{C}$ in Luria-Bertani (LB) medium (Miller, 1991), and P. denitrificans and $R$. sphaeroides strains were normally grown at $30^{\circ} \mathrm{C}$ in Brain-Heart Infusion (BHI) (Miller, 1991) or 290A (Calero et al., 1994) media, respectively. Antibiotics were added to the culture media at the appropriate concentrations for each bacterial species (Miller, 1991).

General genetic techniques. Plasmid DNA was transformed into competent $E$. coli cells as described by Silhavy et al. (1984). Bacterial matings were carried out as reported previously (Fernández de Henestrosa \& Barbé, 1994). Mitomycin $\mathrm{C}$ treatment was performed as described previously (Barbé $e t$ al., 1985).

Biochemical, and RNA and DNA methods. $\beta$-Galactosidase activity assays, RNA extraction, DNA techniques and gel mobility experiments were as reported previously (Fernández de Henestrosa et al., 1998). In all shift mobility experiments, the protein concentration of the crude cellular extract, when used, was $2.5 \mu \mathrm{g} \mathrm{ml}^{-1}$. In the competition experiments with a specific DNA, a 100-fold molar excess of unlabelled DNA was always added to the reaction mixture.

To determine the transcriptional starting point of the $P$. denitrificans recA gene, the oligonucleotide 5' GAACTGCC-

Table 1. Bacterial strains and plasmids used in this work

\begin{tabular}{|c|c|c|}
\hline Strain/plasmid & Description & Source/reference \\
\hline \multicolumn{3}{|l|}{ Strains } \\
\hline \multicolumn{3}{|l|}{ E. coli $\mathrm{K}-12$} \\
\hline $\mathrm{DH} 5 \alpha \mathrm{F}^{\prime}$ & $\begin{array}{l}\text { recA1 endA1 bsdR17 supE44 tbi-1 gyrA96 relA1 } \Delta(\text { lacZYA- } \\
\text { argF)U169 deoR } \phi 80 \mathrm{~d} l a c Z M 15 \mathrm{~F}\end{array}$ & Clontech \\
\hline MC1061 & $\begin{array}{l}\Delta l a c X 74 \text { bsdR mcrB araD139 } \Delta(\text { araABC-leu }) 7679 \text { galU galK } \\
\text { rpsL thi }\end{array}$ & $\begin{array}{l}\text { M. Casadaban, University of } \\
\text { Chicago, USA }\end{array}$ \\
\hline \multicolumn{3}{|l|}{ P. denitrificans } \\
\hline PD1222 & Rif $^{R}$ derivative of the wild-type strain & $\begin{array}{l}\text { J. D. Wall, University of } \\
\text { Missouri, USA }\end{array}$ \\
\hline UAP10 & PD1222 but rec $A:: \Omega \mathrm{Km}$ & $\begin{array}{l}\text { Fernández de Henestrosa et al. } \\
\text { (1997) }\end{array}$ \\
\hline \multicolumn{3}{|l|}{ R. sphaeroides } \\
\hline UA8000 & Rif $^{\mathrm{R}}$ derivative of the wild-type strain & Calero et al. (1994) \\
\hline \multicolumn{3}{|l|}{ Plasmids } \\
\hline $\operatorname{pBSK}(+)$ & $A m p^{R}$ & Stratagene \\
\hline pGEM-T & $\mathrm{Amp}^{\mathrm{R}}$ & Promega \\
\hline pUj8 & Promoterless vector for making lacZ fusions, $A m p^{R}$ & de Lorenzo et al. (1990) \\
\hline pLV106 & Broad-host-range plasmid, $\mathrm{Tc}^{\mathrm{H}} \mathrm{Mob}^{+}$ & Lee \& Kaplan (1992) \\
\hline pRK2013 & $\mathrm{Tra}^{+}$ColE1 replicon $\mathrm{Km}^{\mathrm{R}}$ & $\begin{array}{l}\text { H. D. Helinski, University of } \\
\text { California, USA }\end{array}$ \\
\hline pUA 617 & $\begin{array}{l}\text { pBSK }(+) \text { carrying } P \text {. denitrificans recA gene in a } 3 \mathrm{~kb} \\
\text { EcoRI fragment }\end{array}$ & $\begin{array}{l}\text { Fernández de Henestrosa et al. } \\
\text { (1997) }\end{array}$ \\
\hline pUA 699 & $\begin{array}{l}\text { As pLV106 but carrying the } P \text {. denitrificans wild-type } \\
\operatorname{rec} A: \text { : lac } Z \text { fusion }\end{array}$ & This work \\
\hline pUA 700 & $\begin{array}{l}\text { As pLV } 106 \text { but carrying the } P \text {. denitrificans } \mathrm{OL} \operatorname{rec} A: \text { :lac } Z \\
\text { fusion }\end{array}$ & This work \\
\hline pUA 701 & $\begin{array}{l}\text { As pLV106 but carrying the } P \text {. denitrificans } \text { OR recA:: lac } Z \\
\text { fusion }\end{array}$ & This work \\
\hline pUA 694 & $\begin{array}{l}\text { As pLV106 but carrying the } P \text {. denitrificans wild-type } \\
\text { uvrA:: lacZ fusion }\end{array}$ & This work \\
\hline pUA 702 & $\begin{array}{l}\text { As pLV106 but carrying the } P \text {. denitrificans OL uvr } A: \text { : lac } Z \\
\text { fusion }\end{array}$ & This work \\
\hline pUA 703 & $\begin{array}{l}\text { As pLV106 but carrying the } P \text {. denitrificans } \text { OR uvrA::lac } Z \\
\text { fusion }\end{array}$ & This work \\
\hline
\end{tabular}


Table 2. Oligonucleotide primers used in this work

\begin{tabular}{|c|c|c|c|}
\hline Primer & Sequence* & Position $†$ & Use \\
\hline L1 & $5^{\prime}$ TCGAAAAGTGTTGCCCC 3' & +20 & $\begin{array}{l}\text { Lower primer, } 5^{\prime} \text { digoxigenin end-labelled; used } \\
\text { in the construction of probes for mobility shift } \\
\text { assays (Fig. } 2 b \text { ) }\end{array}$ \\
\hline LF & 5' GGATCCTCGAAAAGTGTTGCCCC 3' & +20 & Lower primer used in $\operatorname{rec} A$ fusion constructions \\
\hline LPE & 5' GAACTGCCGTTCGATCTGGGCC 3' & +96 & $\begin{array}{l}\text { Lower primer used for primer extension } \\
\text { experiments }\end{array}$ \\
\hline UR 1 & 5' GAGGCGCAAATAGGAACA 3' & -90 & Upper primer used to obtain P1 probe (Fig. 2b) \\
\hline UR2 & $5^{\prime}$ CGTGAACAAAGTGGCGG $3^{\prime}$ & -69 & Upper primer used to obtain P2 probe (Fig. $2 b$ ) \\
\hline UF1 & 5' GAATTCAGGACTTGCATTTCGGCG 3' & -112 & Upper primer used to obtain fusion constructions \\
\hline UF2 & $\begin{array}{l}5^{\prime} \text { GAATTCAGGACTTGCATTTCGGCGCAATG } \\
\text { AGGCGCAAATAGGCCCAACCCGTG 3' }\end{array}$ & -112 & $\begin{array}{l}\text { Upper primer used to obtain the mutagenized } \\
\text { recA OL probe; also used in mutagenized fusion } \\
\text { constructions }\end{array}$ \\
\hline UF3 & $\begin{array}{l}\text { 5' GAATTCAGGACTTGCATTTCGGCGCAATG } \\
\text { AGGCGCAAATAGGAACAACCCGTGCCCCA } \\
\text { AAGTGG 3' }\end{array}$ & -112 & $\begin{array}{l}\text { Upper primer used to obtain the mutagenized } \\
\text { recA OR probe; also used in mutagenized fusion } \\
\text { constructions }\end{array}$ \\
\hline LUF1 & $5^{\prime}$ AGGACTTGCCCGAGC $3^{\prime}$ & +122 & $\begin{array}{l}\text { Lower primer used to obtain wild-type } u v r A \\
\text { fusion }\end{array}$ \\
\hline LUF2 & 5' GGATCCGCCCGAGCCCGACAGGCCGG 3' & +111 & $\begin{array}{l}\text { Lower primer used to obtain } u v r A \text { probes; also } \\
\text { used in mutagenized fusion }\end{array}$ \\
\hline UV1 & 5' GCCGCATTGGCAGCCGCC 3' & -189 & $\begin{array}{l}\text { Upper primer used to obtain wild-type } u v r A \\
\text { fusion }\end{array}$ \\
\hline UV2 & $5^{\prime}$ CCTGCATGGTTGGGGCAGGG 3' & -126 & Upper primer used to obtain $u v r A$ probe (Fig. $2 \mathrm{~b}$ ) \\
\hline UV3 & $\begin{array}{l}\text { 5' GAATTCCCTGCATGGTTGGGGCAGGGCTG } \\
\text { CCAGGGGCCGCAAGCCGGAAATGCCCCTG } \\
\text { TGATG 3' }\end{array}$ & -126 & $\begin{array}{l}\text { Upper primer used to obtain the mutagenized } \\
\text { uvrA OL probe; also used in mutagenized fusion } \\
\text { constructions (Fig. 2b) }\end{array}$ \\
\hline UV4 & $\begin{array}{l}\text { 5' GAATTCCCTGCATGGTTGGGGCAGGGCT } \\
\text { GCCAGGGGCCGCAAGCCGGAAATGTTCCT } \\
\text { GTGATGCCCTGTTTG } 3^{\prime}\end{array}$ & -126 & $\begin{array}{l}\text { Upper primer used to obtain the mutagenized } \\
\text { uvrA OR probe; also used in mutagenized fusion } \\
\text { constructions (Fig. } 2 \text { b) }\end{array}$ \\
\hline
\end{tabular}

* Nucleotide changes are in bold and underlined. Added restriction sites are in italics.

† Distance from the $5^{\prime}$ end of the oligonucleotide to either the transcriptional or the translational starting point of $P$. denitrificans recA and $u v r A$ genes, respectively.

GTTCGATCTGGGCC 3', which hybridizes to nucleotides +75 to +96 relative to the translational starting site, was used. This primer was synthesized and $5^{\prime}$ end-labelled with digoxigenin-N-hydroxysuccinimide ester (MWG-Biotech). Primer extension was carried out as previously reported (Tapias et al., 1997).

The nucleotide sequence of the $P$. denitrificans $u v r A$ gene was determined from both DNA strands by the dideoxy method (Sanger et al., 1977) on an ALF Sequencer (Pharmacia Biotech).

Primers used in the construction of the different $P$. denitrificans recA and $u v r A$ probes, supplied by Boehringer Mannheim, are presented in Table 2. To facilitate subcloning of PCR-DNA fragments and construction of the lacZ fusions, specific restriction sites (shown in Table 2) were incorporated into the oligonucleotide primers. The DNA sequence of all PCRmutagenized fragments was obtained in all cases from both DNA strands.

Construction of lac $Z$ fusions. To construct the several recA-lac Z fusions used in this work a $250 \mathrm{bp}$ PCR product containing the recA promoter and $138 \mathrm{nt}$ of its coding region of either the wild-type or the desired mutant was cloned in the pGEM-T vector (Promega). In the same way, the $u v r A-l a c Z$ fusions were constructed with a $240 \mathrm{bp}$ PCR-amplified fragment of either the wild-type promoter or the desired mutants
(Table 2) containing $114 \mathrm{bp}$ of the $u v r A$ coding region. For each fusion, desired restriction fragments were recovered from the appropriate pGEM-T derivative and subcloned into the pUJ8 plasmid upstream of the promoterless $\operatorname{trp} p^{\prime}-{ }^{\prime} l a c Z$ region. Afterwards, the Not I fragment harbouring the created fusion was recovered from the agarose gel, filled with T4 DNA polymerase to obtain blunt ends and inserted into the single Smal cloning site of the pLV106 plasmid. The presence of the desired mutations was again tested by DNA sequencing of each fusion using the $5^{\prime}$ fluorescein CGAACGGCCAGTGAATCCG $3^{\prime}$ primer, which extended from nucleotides +32 to +14 , with respect to the translational starting point of the $E$. coli lacZ gene. Finally, plasmids containing the constructed fusions were introduced by mating into $P$. denitrificans cells.

\section{RESULTS}

\section{Characterization of the Paracoccus denitrificans recA transcriptional starting point}

It has been reported that some rec $A$ genes are expressed from a polycistronic transcript (Martin et al., 1995). To determine whether this was the case in the $P$. denitrificans recA gene, and also to locate its putative regulatory sequences, the transcriptional starting point 
(a)

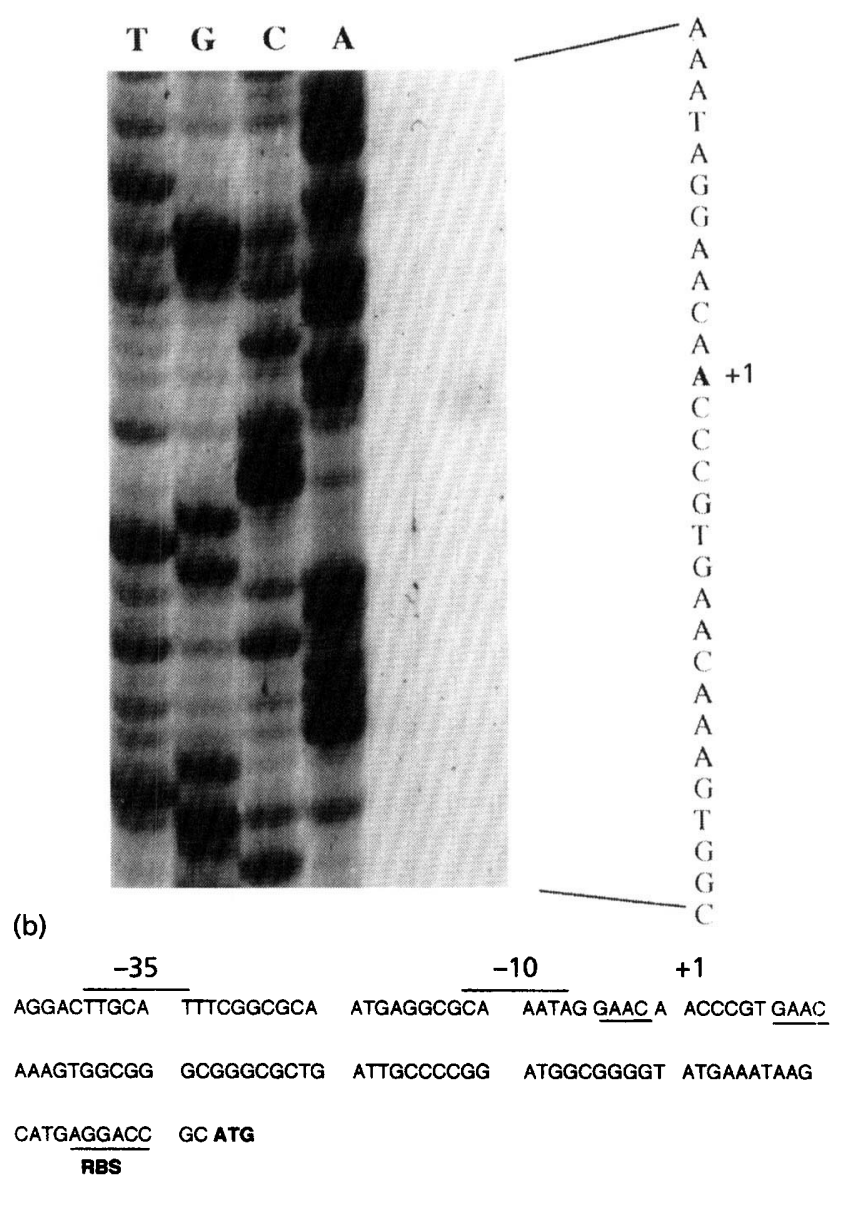

Fig. 1. (a) Determination of the $5^{\prime}$ end of the $P$. denitrificans recA transcript by primer extension. Lanes T, C, G and A contain products of sequencing reactions of plasmid pUA617 carried out with the same primer as used for primer extension. The transcriptional starting point is indicated $(+1)$. (b) Nucleotide sequence of the $P$. denitrificans recA upstream region. The +1 position, the predicted $-10,-35$ and ribosome-binding site (RBS) sequences, and the translational starting point are indicated. The GAACN ${ }_{7} G A A C$ direct repeat present in the upstream region of the recA gene is underlined.

of this gene was identified by primer extension experiments using total RNA isolated from $P$. denitrificans PD1222 cells in the presence of mitomycin C at $10 \mu \mathrm{g}$ $\mathrm{ml}^{-1}$. The main signal obtained was the A nucleotide located 72 bp upstream of the site previously predicted as the putative translational starting codon (Fig. 1a). In agreement with these results, the putative -35 and -10 sites could be TTGCAT and CAAATA, respectively (Fig. 1b).

\section{Isolation of the $\boldsymbol{P}$. denitrificans uvrA gene}

To determine whether a given sequence is the regulatory element of a gene network, this sequence must be present in all genes of the network. For this reason, it was decided to isolate the $P$. denitrificans $u v r A$ gene. In this way, the promoter sequences of both genes could be compared and the relationship existing between them analysed in vivo and in vitro. To isolate the $P$. denitrificans uvrA, the same strategy used to clone its recA gene was employed, taking advantage of the phylogenetic relationship existing between $P$. denitrificans and $R$. sphaeroides (Fernández de Henestrosa et al., 1997). Thus, a gene bank of $P$. denitrificans constructed in the $\lambda$ GEM12 vector was probed with a $0.3 \mathrm{~kb}$ SacII internal fragment of the $R$. sphaeroides uvrA gene (Mackenzie et al., 1995). Among 1200 plaques screened, four reacted with the probe. One of these positive phage was analysed by restriction enzyme digestion and Southern blot hybridization. A $5 \mathrm{~kb} S \mathrm{maI}$ fragment of this phage, which hybridizes with the $R$. sphaeroides probe, was isolated and ligated into the single SmaI site of the pBluescript $\mathrm{SK}(+)$ plasmid. Further subcloning and sequencing experiments have enabled us to obtain the nucleotide sequence of the promoter and the $5^{\prime}$ end coding region of the $P$. denitrificans uvrA gene.

It is known that not all $u v r A$ genes are DNA-damageinducible. Thus, it has been demonstrated that expression of the Pseudomonas aeruginosa and Neisseria gonorrboeae uvrA genes is not triggered following DNA damage (Rivera et al., 1997; Black et al., 1998). For this reason, it was decided to analyse the behaviour of the $P$. denitrificans uvrA promoter towards DNA injury. To do this, the pUA694 plasmid containing a uvrA-lacZ fusion (constructed as reported in Methods) was introduced into a $\mathrm{Rif}^{\mathrm{R}}$ mutant of $P$. denitrificans. Addition of mitomycin $C$ to $P$. denitrificans (pUA694) cells induced the expression of the $u v r A$-lac $Z$ fusion in $\mathrm{RecA}^{+}$but not in $\mathrm{RecA}^{-}$cells, indicating that this inducibility is recAdependent (data not shown).

\section{Electrophoretic mobility of the $P$. denitrificans recA and uvrA promoters}

The above-established +1 position of the $P$. denitrificans recA gene overlaps with the $\mathrm{GAACN}_{7} \mathrm{GAAC}$ direct repeat (Fig. 1b). This motif, GAACN GAAC, is $_{7}$ also present upstream of the $R$. sphaeroides recA gene and controls its DNA-damage-mediated expression (Fernández de Henestrosa et al., 1998). Gel retardation experiments were therefore carried out with different derivatives of the $P$. denitrificans recA promoter to determine whether a protein binds to its GAACN ${ }_{7}$ GAAC motif. Fig. 2(b) shows that the mobility of a DNA fragment containing the GAACN ${ }_{7}$ GAAC sequence shifts in the presence of $P$. denitrificans cell extract. On the other hand, no changes were detected in the mobility of a fragment lacking the GAACN GAAC $_{7}$ motif (Fig. 2b, lane 4). This DNA-protein complex is formed by the binding of a sequence-specific protein to the probe since the addition of unlabelled pBSK-DNA did not affect the formation of the DNA-protein complex (Fig. 2b, lane 6), whereas the presence of unlabelled wild-type recA promoter inhibited it (Fig. 2b, lane 7). Furthermore, the addition of competitor fragments carrying a mutation in any of the two GAAC 
(a)

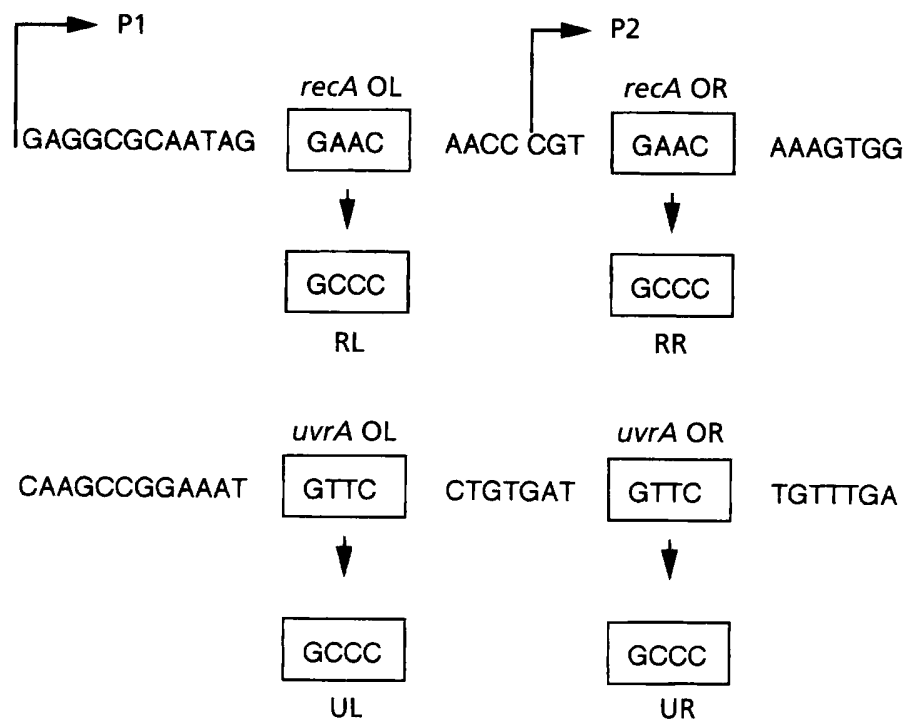

(b)

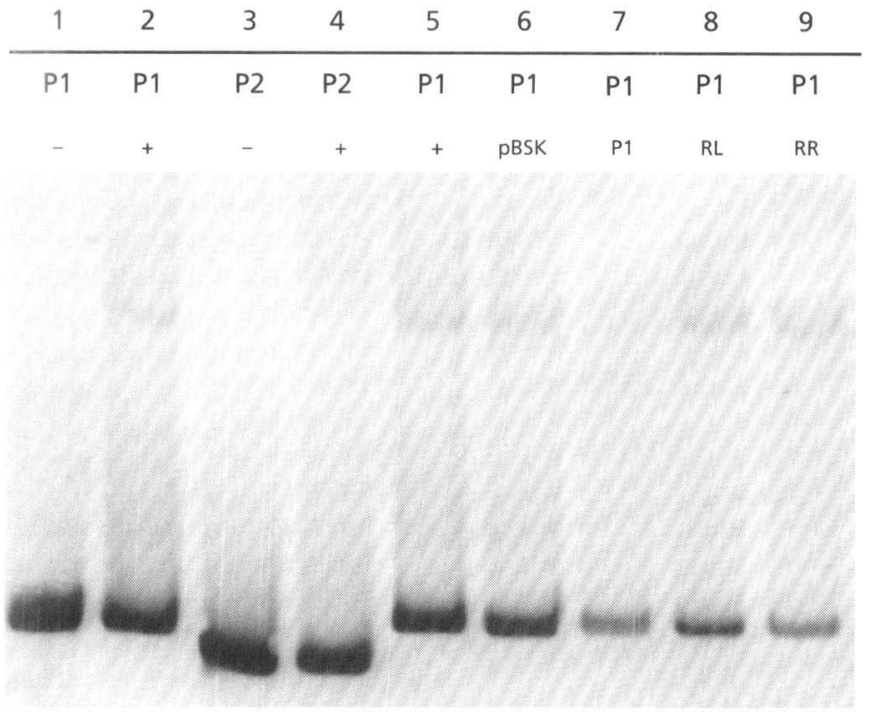

\begin{tabular}{ccccc}
10 & 11 & 12 & 13 & 14 \\
\hline P1 & P1 & P1 & P1 & P1 \\
- & + & uvrA & UL & UR \\
& & & & \\
& & & \\
& & \\
&
\end{tabular}

Fig. 2. (a) Sequence of the operator regions of the $P$. denitrificans recA and uvrA genes. $P 1$ and $P 2$ indicate the starting point of the upper primers used to obtain fragments containing the recA gene employed in gel mobility experiments. The changes introduced by PCR mutagenesis in the GAACN, GAAC and GTTCN, GTTC direct repeats present in the operators of the recA and uvrA genes, respectively, are also indicated. (b) Gel mobility of the recA promoter of $P$. denitrificans under several experimental conditions. Lanes 1-4 show the behaviour of P1 and P2 fragments in the absence $(-)$ or in the presence $(+)$ of $P$. denitrificans crude cell extract. Lanes 5-9 show the mobility of the $P 1$ fragment (lane 5 ) in the presence of $P$. denitrificans crude extract as well as the effect on this mobility of unlabelled 100 -fold molar excess of PBSK-DNA (lane 6), P1 fragment (lane 7), or mutants RL and RR of the P1 fragment (lanes 8 and 9, respectively). The effect of an excess of unlabelled-fragment containing either the wild-type or mutant derivatives of the $P$. denitrificans uvrA promoter on the mobility of the P1 fragment in the presence of crude extract is also shown (lanes 12-14). All binding assays were done simultaneously, although competitive experiments with uvrA fragments (lanes 12-14) were run in a different gel. For this reason, and as an experimental control, the mobility of the P1 fragment is also included in lanes 10-11.

submotifs of the GAACN $\mathrm{GAAC}_{7}$ sequence does not affect the band shift (Fig. 2b, lanes 8 and 9). All these data indicate that the binding of the protein requires the presence of the $\mathrm{GAACN}_{7} \mathrm{GAAC}$ sequence. It is worth noting that the same protein binds to the $P$. denitrificans uvrA promoter since its presence prevents $P$. denitrificans recA-protein complex formation (Fig. 2b, lane 12).

The gel retardation experiments indicate that a protein binds the promoters of both recA and uvrA of $P$. denitrificans. Between the -66 and -91 positions, with 
Table 3. Effects of mutations on the expression of the $P$. denitrificans rec $A$ and uvrA genes measured as the $\beta$-galactosidase specific activity of recA-lacZ and uvrA-lacZ fusions

\begin{tabular}{|c|c|c|c|}
\hline \multirow[t]{2}{*}{ Plasmid } & \multicolumn{3}{|c|}{$\beta$-Galactosidase specific activity (units) ${ }^{*}$} \\
\hline & Basal level & Induced level & Induction factor $†$ \\
\hline pUA699 (recA wild-type) & 1200 & 2600 & $2 \cdot 2$ \\
\hline pUA700 $\left(\mathrm{rec} A \mathrm{OL}^{-}\right)$ & 6500 & 6600 & 1 \\
\hline pUA701 (recA OR $\left.{ }^{-}\right)$ & 6400 & 6500 & 1 \\
\hline pUA694 (uvrA wild-type) & 1600 & 6800 & $4 \cdot 2$ \\
\hline pUA702 (uvrA OL") & 4800 & 5000 & 1 \\
\hline pUA703 (uvrA OR $\left.{ }^{-}\right)$ & 6600 & 6700 & 1 \\
\hline
\end{tabular}

$* \beta$-Galactosidase specific activities were measured in the absence of mitomycin $\mathrm{C}$ (basal level) or $180 \mathrm{~min}$ after the addition of this compound at $10 \mu \mathrm{g} \mathrm{ml}^{-1}$ (induced level). All determinations are the means of at least three experiments (each in triplicate), and a single standard error of any value was never greater than $10 \%$.

†The induction factor is the ratio between the specific activity of $\beta$-galactosidase of mitomycin Ctreated cells and the specific activity in non-treated cells for each strain.

respect to the $u v r A$ translational starting point, the $u v r A$ promoter contains the GTTCN ${ }_{7}$ GTTC sequence, which corresponds to the reverse and complementary sequence of the GAACN $\mathrm{GAAC}_{7}$ motif present in the $P$. denitrificans recA gene (Fig. 2a). The $R$. sphaeroides uvrA promoter also contains a GTTCN $\mathrm{N}_{7}$ GTTC motif which controls its DNA-damage-mediated induction (Fernández de Henestrosa et al., 1998). For this reason, the electrophoretic mobility of mutant derivatives of the $P$. denitrificans uvrA promoter was studied. A $P$. denitrificans $u v r A$ promoter mutagenized in either the first or the second direct repeat of the GTTCN ${ }_{7}$ GTTC sequence did not inhibit the band shift detected when the $P$. denitrificans $\operatorname{rec} A$ promoter was incubated in the presence of crude cell extract (Fig. 2b, lanes 13 and 14).

\section{Effect of operator mutations upon $\boldsymbol{P}$. denitrificans recA and uvrA gene expression}

The results shown above demonstrate that the same protein binds to the $\mathrm{GAACN}_{7} \mathrm{GAAC}$ and GTTCN $_{7}$ GTTC sequences present upstream of the $P$. denitrificans recA and uvrA genes, respectively. To determine whether these sequences are the regulatory elements of both genes, the effect of several mutations in these sequences upon the in vivo expression of these two genes was analysed. To do this, different lac $Z$ fusions were constructed with derivatives of both $r e c A$ and $u v r A$ promoter fragments carrying the same mutations as those used in the gel mobility experiments. The fusion constructs were introduced into $P$. denitrificans using the pLV106 plasmid. Table 3 shows that cells carrying any of the mutations tested demonstrated a constitutive and high level of $\beta$-galactosidase synthesis, indicating that the control of $P$. denitrificans rec $A$ and $u v r A$ genes requires the GAACN ${ }_{7}$ GAAC and GTTCN $_{7}$ GTTC sequences, respectively. The reason why the basal level of the deregulated recA mutants is higher than the induced level achieved by the wild-type fusion following mitomycin $\mathrm{C}$ treatment is unknown. However, one possibility could be that the concentration of mitomycin $C$ used was not the optimal amount to obtain the maximum DNA-damage-mediated induction of the recA gene. In fact, similar behaviour has been described in E. coli cells (Krueger et al., 1983; Wertman \& Mount 1985). Finally, the expression of the wild-type and $\mathrm{OR}^{-}$ $P$. denitrificans recA promoters is either DNA-damageinducible or constitutive when introduced into $R$. sphaeroides cells, respectively (data not shown).

\section{DISCUSSION}

We have previously shown that GTTCN ${ }_{7}$ GATC and GAACN ${ }_{7}$ GAAC motifs control the DNA-damagemediated induction of the $R$. sphaeroides recA gene. Likewise, we have also demonstrated that the GTTCN $_{7}$ GTTC motif regulates the induction of the $R$. sphaeroides uvrA gene. Since the GAACN ${ }_{7}$ GAAC motif is the reverse and complementary sequence of GTTCN ${ }_{7}$ GTTC, together with the fact that the GTTCN $N_{7}$ GATC and GTTCN ${ }_{7}$ GTTC motifs are also present in both DNA-damage-inducible genes, we have proposed the GTTCN ${ }_{7}$ GTTC motif as the SOS box of R. sphaeroides (Fernández de Henestrosa et al., 1998). In the present study, it has been established that the GAACN $\mathrm{GAAC}_{7}$ and GTTCN $_{7}$ GTTC motifs control the expression of the $P$. denitrificans $r e c A$ and $u v r A$ genes, respectively. Thus it is clear that the $R$. sphaeroides and $P$. denitrificans uvrA genes have the same regulatory sequence (GTTCN ${ }_{7}$ GTTC), whereas the $\operatorname{rec} A$ genes of these two organisms differ in the presence of a second regulatory sequence in one of them: in both $\operatorname{recA}$ genes the GAACN ${ }_{7}$ GAAC sequence is found, but the $R$. sphaeroides rec $A$ gene also has the GTTCN ${ }_{7}$ GTAC motif. Furthermore, expression of the $P$. denitrificans recA gene is triggered by DNA damage in $R$. sphaeroides cells unless the GAACN ${ }_{7}$ GAAC motif is mutagenized. These data are in agreement with the fact that $P$. denitrificans and $R$. sphaeroides have both 
been phylogenetically classified within the $x$-subclass of the Proteobacteria.

In this context, and in agreement with our previous work (Fernandez de Henestrosa et al., 1998), we propose

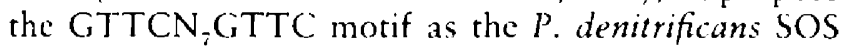
box. From a biological point of vicw, and despite the sequences being different with respect to the transcriptional sense, the mechanism by which the LexA repressor of $P$. denitrificans binds to cither recA (GAACN-GAAC) or wrA (CTTCN $\mathrm{N}_{7}$ GTTC) operators must be the same since, in fact, the sequences of both motifs (which are a direct repeat) are complementary and reverse. In this respect, it is also worth noting that the sequence of the $R$. sphaeroides and $P$. denitrificans SOS box shows several specific and different properties from either of the other $S O S$ boxes or protein-binding sequences described. The first is that this sequence is a direct repeat instead of a palindrome. The second is that, to our knowledge, this is the only case shown where the controlling sequences of two genes of the same regulatory network are found in the opposite orientation in each of them. Because of these characteristics, the model LexA repressor-SOS box of $P$. denitrificans mav be very useful for progressing knowledge of DNA-protein interactions in bacteria.

\section{ACKNOWLEDGEMENTS}

This work was funded by grants PB94-0687 and PB97-0194 of the Direcicion General de Investigación Cientifica y Tecnica of Spain (I) (iICYT) and partially supported by the Comissionat per Unversitats i Recercia de la Cieneralitat de Catalunya. Alfonse del Rey was a recipient of a predoctoral fellowship from the Direcici General d'Universitats de la Generalitat de Catalunya. We gratefully acknowledge the help of the Direcio General d'iniversitats de la (ieneralitat de Catalunya for different grants for the purchase of equipment. We are deeply indebted to Joan Ruiz and M. Mar Lopez for their excellent technicial assistance. We thank Dr V. de I orenzo, for supplying several strains and plasmids.

\section{REFERENCES}

Barbé, J., Vericat, J. A., Cairó, J. \& Guerrero, R. (1985). Further characturization of SOS system induction in recBC: mutants of Escherichia coli. Mutut Res 146, 23-32.

Black, C. G., Fyfe, J. A. M. \& Davies, J. K. (1998). Absence of an SOS-like system in Neisseria gonorrboeae. Gene 208, 61-66.

Calero, S., Fernández de Henestrosa, A. R. \& Barbé, J. (1994). Molecular cloning, sequence and regulation of the rec $A$ gene of the phototrophic hacterium Rhodobacter sphaeroides. Mol Gen (ienet 242. 116-120.

Cheo, D. L., Bayles, K. W. \& Yasbin, R. E. (1991). Cloning and characterization of DNA damage-inducible promoter regions from Busillus subthis. J Bacteriol 173, 1696-1703.

Durbach, S. I., Andersen, S. J. \& Mizrahi, V. (1997). SOS induction in mycobacteria : analysis of the D.NA-binding activity of a LexAlike repressor and its role in DNA damage induction of the recA gene trom Mycobacterium smegmatis. Mol Microbiol 26, $64.3-6.5 .3$

Fernández de Henestrosa, A. R. \& Barbé, J. (1994). Autoregulation and kinetics of induction of the Rbizotium phaseoli recA gene. Mutat Re's 308, 9y-107.
Fernández de Henestrosa, A. R., del Rey, A., Tarragó, R. \& Barbé, J. (1997). Cloning and characterization of the recA gene of Puracocus denitrificans and construction of a recA-deficient mutant. FF.MS Microbiol Lett 147, 209-213.

Fernández de Henestrosa, A. R., Rivera, E., Tapias, A. \& Barbé, J. (1998). Identification of the Rhodobacter sphaeroides SOS hox. Mol Microbiol 28, 991-1003.

Garriga, X., Calero, S. \& Barbé, J. (1992). Nuclcotide sequence analysis and comparison of the lexA genes from Salmonella typhimurium, Fruina carototora, Pseadomonas aeruginosa and Pseudomonas putida. Mol (ien (ienet 236, 125-134.

Johnston, J. L., Sloan, J., Fyfe, J. A. M., Davies, J. K. \& Rood, J. I. (1997). The rec A gene from Clostridium perfringens is induced by methyl methanesulphonate and contains an upstream (heo box. Microbiology 143, 885-890.

Krueger, J. H., Elledge, S. J. \& Walker, G. C. (1983). Isolation and characterization of $\mathrm{T} n .5$ insertion mutations in the lexA gene of Fscherichia coli. J Bacteriol 153,1368-1378.

Lee, J.K. \& Kaplan, S. (1992). cis-Acting regulatory elements involved in oxygen and light control of pac operon transcription in Rhodobacter sphaeroides. J Bacteriol 174, 1146-11.57.

Lewis, L. K., Harlow, G. R., Gregg-Jolly, L. A. \& Mount, D. W. (1994). Identification of high affinity binding siles for LexA which define new DNA damage-inducible genes in Fsiberichia coli. I Mol Biol 241, 507-523.

Little, J.W. (1991). Mechanism of specitic lexA cleavage: autodigestion and the role of Rect coprotease. Biochimip 73, 411-422.

Little, J. W. \& Mount, D. W. (1982). The SOS regulatory system of Fischerichia coli. (iell 29, 11-22.

de Lorenzo, V., Herrero, M., Jakubzik, U. \& Timmis, K. N. (1990). Mini-Tns transposon derivatives for insertion mutagenesis, promoter probing, and chromosomal insertion of cloned DNA in Gram-negative eubacteria. I Bacteriol 172, 6.568-65>2.

Mackenzie, C., Chidambaram, M., Sodergren, E. J., Kaplan, S. \& Weinstock, G. M. (1995). DNA repair mutants of Rhodobiater sphaeroides. / Bacleriol 177, 3027-3035.

Martin, B., Garcia, P., Castanie, M. P. \& Claverys, J. P. (1995). The recA gene of Streptococas pneumoniac is part of a competenceinduced operon and controls lysogenic induction. Mol Microbiol $15,367-379$.

Miller, J. H. (1991). Bacterial genetic systems. Methods Enzymol 204, 459-48.5.

Miller, R. V. \& Kokjohn, T. A. (1990). Ciencral microbiology of recA. Fnvironmental and evolutionary significance. Ammu Rev Microbiol 44, 365-394.

Movahedzadeh, F., Colston, M. J. \& Davis, E. O. (1997). Characterization of Mycobacteritum tuberculosts LexA : recognition of a Cheo (Bacillus-type SOS) box. Microbiology' 143, 929-936.

Raymond-Denise, A. \& Guillen, N. (1991). Identification of $d i n R$, a DNA damage-inducible regulator gene of Bacillus subtilis. J Batteriol 173, 7084-7091.

Rivera, E., Vila, L. \& Barbé, J. (1997). Expression of the Pseudomonus aeruginosa uvrA gene is consticutive. Mutat Res $377,149-155$.

Roca, A. I. \& Cox, M. M. (1997). Rect protein : structure, function, and role in recombinational D.NA repair. Prog Nucleic Acid Res Mol Biol 56, 129-223.

Sanger, F., Nicklen, S. \& Coulson, A. R. (1977). INA sequencing with chain-terminating inhibitors. Proc Nat Acad $S_{C}$ L LSA 74 , $546.3-5467$. 
Sassanfar, M. \& Roberts, J. W. (1990). Nature of the SOS-inducing signal in Escherichia coli. The involvement of DNA replication. $J$ Mol Biol 212, 79-96.

Silhavy, T. J., Berman, M. L. \& Enquist, L. W. (1984). Experiments with Gene Fusion. Cold Spring Harbor, NY: Cold Spring Harbor Laboratory.

Tapias, A., Fernández de Henestrosa, A. R. \& Barbé, J. (1997). Characterization of the promoter of the Rhizobium etli rec $A$ gene. J Bacteriol 179, 1573-1579.

Walker, G. C. (1984). Mutagenesis and inducible responses to deoxyribonucleic acid damage in Escherichia coli. Microbiol Rev 48, 60-93.

Wertman, K. F. \& Mount, D. (1985). Nucleotide sequence binding specifity of the LexA repressor of Escherichia coli K-12.J Bacteriol $163,376-384$.

Winterling, K. W., Chafin, D., Hayes, J. J., Sun, J., Levine, A. S., Yasbin, R. E. \& Woodgate, R. (1998). The Bacillus subtilis DinR binding site: redefinition of the consensus sequence. J Bacteriol 180, 2201-2211.

Woese, C. R., Stackebrandt, E., Weisburg, W. G. \& 8 other authors (1984). The phylogeny of purple bacteria: the alpha subdivision. Syst Appl Microbiol 5, 315-326.

Received 3 September 1998; revised 6 November 1998; accepted 25 November 1998. 